\title{
Action Potential Generation at an Axon Initial Segment-Like Process in the Axonless Retinal AII Amacrine Cell
}

\author{
Chaowen Wu, Elena Ivanova, Jinjuan Cui, Qi Lu, and Zhuo-Hua Pan \\ Department of Anatomy and Cell Biology, Wayne State University School of Medicine, Detroit, Michigan 48201
}

In axon-bearing neurons, action potentials conventionally initiate at the axon initial segment (AIS) and are important for neuron excitability and cell-to-cell communication. However in axonless neurons, spike origin has remained unclear. Here we report in the axonless, spiking AII amacrine cell of the mouse retina a dendritic process sharing organizational and functional similarities with the AIS. This process was revealed through viral-mediated expression of channelrhodopsin-2-GFP with the AIS-targeting motif of sodium channels $\left(\mathrm{Na}_{\mathrm{v}} \mathrm{II}-\mathrm{III}\right)$. The AII processes showed clustering of voltage-gated $\mathrm{Na}^{+}$channel $1.1\left(\mathrm{Na}_{\mathrm{v}} 1.1\right)$ as well as AIS markers ankyrin-G and neurofascin. Furthermore, $\mathrm{Na}_{\mathrm{v}} \mathrm{II}$-III targeting disrupted $\mathrm{Na}_{\mathrm{v}} 1.1$ clustering in the AII process, which drastically decreased $\mathrm{Na}^{+}$current and abolished the ability of the AII amacrine cell to generate spiking. Our findings indicate that, despite lacking an axon, spiking in the axonless neuron can originate at a specialized AIS-like process.

\section{Introduction}

Sites of action potential generation have been implicated as important sources of neuronal plasticity and neuronal signaling optimization (Losonczy et al., 2008; Grubb and Burrone, 2010a; Kuba et al., 2010). Although it is known that action potentials typically initiate at the axon initial segment (AIS) in axon-bearing neurons (Coombs et al., 1957; Palmer and Stuart, 2006; Kole et al., 2008), the origin of action potentials in axonless neurons remains poorly understood.

The AII amacrine cell is an axonless interneuron in the mammalian retina known for its crucial role in mediating scotopic (nighttime) vision (Famiglietti and Kolb, 1975; Bloomfield and Dacheux, 2001) and recently also for its involvement in photopic (daytime) vision (Xin and Bloomfield, 1999; Manookin et al., 2008; Münch et al., 2009). The cell is conventionally depicted as a bistratified neuron with the following two distinct dendritic trees: the distal dendrites (arboreal dendrites) terminate in the retinal inner plexiform layer (IPL) ON-sublamina, and the proximal dendrites (lobular appendages) terminate in the OFF-sublamina. AII amacrine cells pass rod signals from rod bipolar cells received through the arboreal dendrites to the ON cone pathway at the arboreal dendrites, and to the OFF cone pathway at the lobular appendages (Bloomfield and Dacheux, 2001) (see Fig. 1a). Al-

\footnotetext{
Received April 13, 2011; revised Aug. 12, 2011; accepted Aug. 19, 2011.

Author contributions: C.W., E.I., J.C., and Z.-H.P. designed research; C.W., E.I., J.C., and Q.L. performed research; C.W., E.I., and J.C. analyzed data; C.W., E.I., and Z.-H.P. wrote the paper.

This work was supported by NIH Grant EY17130, the Wayne State University (WSU) MD/PhD program (C.W.), and NIH Core Grant EY04068 to the Department of Anatomy and Cell Biology at WSU. We thank Drs. R. Andrade and Dennis Goebel for comments on the manuscript.

The authors declare no competing financial interests.

Correspondence should be addressed to Dr. Zhuo-Hua Pan, Department of Anatomy and Cell Biology, Wayne State University School of Medicine, 540 E. Canfield Avenue, Scott Hall 8360, Detroit, MI 48201. E-mail: zhpan@med.wayne.edu.

DOI:10.1523/JNEUROSCI.1861-11.2011

Copyright $\odot 2011$ the authors $\quad 0270-6474 / 11 / 3114654-06 \$ 15.00 / 0$
}

though it is commonly believed that AII amacrine cells primarily use graded potentials for information processing, accumulating evidence suggests that action potentials, or spikes, also play a role (Boos et al., 1993; Veruki and Hartveit, 2002a; Veruki and Hartveit, 2002b; Tamalu and Watanabe, 2007; Tian et al., 2010). $\mathrm{Na}^{+}$ channel-dependent spiking in the AII amacrine cell is well documented (Boos et al., 1993; Tamalu and Watanabe, 2007). A previous study suggested that $\mathrm{Na}^{+}$channels are mainly localized in the soma and the proximal dendrites (Tamalu and Watanabe, 2007) (but see also Tian et al., 2010). The precise location and the nature of spike origin, however, have remained elusive.

In this study, we took advantage of the cell's own protein trafficking machinery (Lai and Jan, 2006) and the high tropism of adeno-associated virus serotype 2 (AAV2/2) for the AII amacrine cell (Ivanova and Pan, 2009) to investigate the spike initiation site within this axonless neuron. Spike generation at the AIS requires voltage-gated $\mathrm{Na}^{+}\left(\mathrm{Na}_{\mathrm{v}}\right)$ channel clustering (Kole et al., 2008). $\mathrm{Na}_{\mathrm{v}} 1$ subunits share a conserved amino acid motif $\left(\mathrm{Na}_{\mathrm{v}} \mathrm{II}-\mathrm{III}\right)$ shown to be necessary and sufficient to target proteins to the AIS (Garrido et al., 2003; Lemaillet et al., 2003). By linking Na $\mathrm{II}-\mathrm{III}$ to channelrhodopsin-2 (ChR2) for membrane anchoring, and GFP for visualization (also see Grubb and Burrone, 2010b), ChR2-GFP-Na $\mathrm{II}-\mathrm{III}$ expression in the AII amacrine cell revealed an AIS-like compartment within its dendritic trees. This suggests that axonless neurons could possess similar compartmental organization as axon-bearing neurons for action potential generation.

\section{Materials and Methods}

DNA and viral vector construction. AAV2/2 cassette carrying the ChR2GFP fusion construct (Bi et al., 2006) was modified by inserting the 27 aa ankyrin binding domain from $\mathrm{Na}_{\mathrm{v}} 1.6\left(\mathrm{Na}_{\mathrm{v}} \mathrm{II}-\mathrm{III}\right.$ : 5' -TVRVPIAVGESDFE NLNTEDVSSESDP-3') (Garrido et al., 2003) at the 3' end of GFP. Virus vectors with CAG (a hybrid CMV early enhancer/chicken $\beta$-actin) promoter were packaged and affinity purified at the Gene Transfer Vector Core of the University of Iowa. 

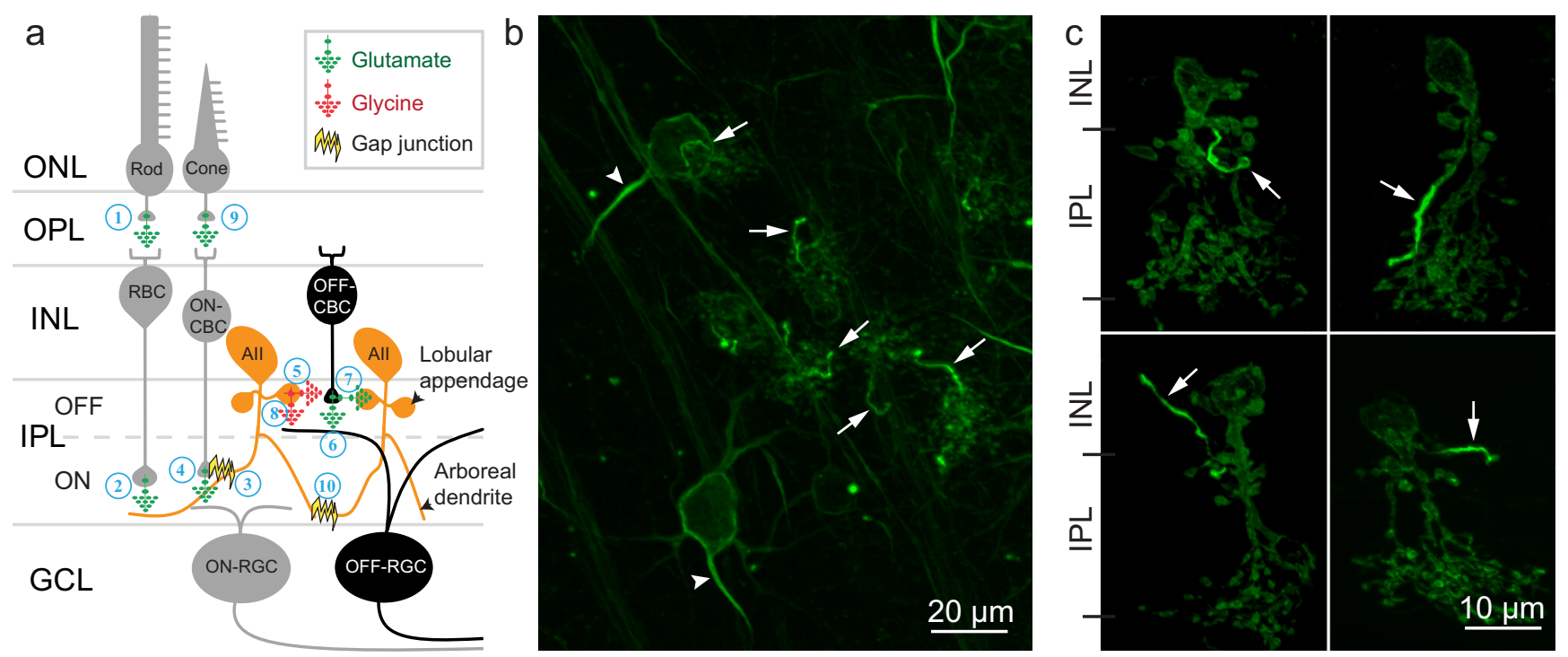

Figure 1. All amacrine cell circuits and ChR2-GFP-Na $\mathrm{VII}-\mathrm{III}$ expression in the retina. $\boldsymbol{a}$, In scotopic vision, rods sense light and excite rod bipolar cells (RBCS) (1); RBCs synapse onto All cell arboreal dendrites that excite $0 \mathrm{~N}$-cone bipolar cells (CBCS) through gap junctions (2-3); ON-CBCs excite ON-RGCS (4); at the same time, All cell lobular appendages inhibit OFF-CBC glutamate release onto OFF-RGCs and receive synaptic feedback from OFF-CBCs (Anderson et al., 2011) (5-7); lobular appendages also directly inhibit OFF-RGCs with glycine (8); therefore, excitation of All cells leads to excitation of ON-pathways and inhibition of OFF-pathways; in photopic vision, cones sense light and excite ON-CBC that may use gap junctions in reverse to excite All cells at the arboreal dendrites leading to inhibition of the OFF-pathway (9) (Manookin et al., 2008; Münch et al., 2009); and finally, All cells are electrically coupled through arboreal dendrite gap junctions (10). 0NL/OPL, Outer nuclear/plexiform layer; $\mathrm{GCL}$, ganglion cell layer; $\boldsymbol{b}$, In retinal flat-mount, $\mathrm{Na}_{\mathrm{v}} \mathrm{II}-\mathrm{Ill}$ expression was concentrated in RGC AIS (arrowheads) and smaller processes (arrows) suspected to belong to All cells. Collapsed $z$-stack image: $20 \times$ objective; $1 \mu \mathrm{m} z$-sections. c, In retinal vertical section, each All cell was observed with one Na $\mathrm{Na}_{\mathrm{V}} \mathrm{IIII}$ targeted process (arrows) of varying direction and conformation originating from the lobular appendages and terminating in both IPL ON- and OFF-sublaminae and in the INL. Collapsed $z$-stack image: $63 \times$ objective; $0.6 \mu \mathrm{m} z$-sections.

Animals and $A A V 2 / 2$ vector injection. All animal experiments and procedures were approved by the Institutional Animal Care Committee at Wayne State University, and were in accord with the NIH Guide for the Care and Use of Laboratory Animals. Adult C57BL/6J mice of either sex aged 1-2 months were used for virus injections. The procedures for virus injection were the same as previously described (Bi et al., 2006). Three groups of animals were injected. The motif-targeted group received injections of AAV2/2-ChR2-GFP-Na $\mathrm{II}-\mathrm{III}$ virus at low and high concentrations of $5 \times 10^{10}$ and $3-13 \times 10^{12}$ genomic particles $(\mathrm{GP}) / \mathrm{ml}$ for histology/immunohistochemistry and patch-clamp recordings, respectively. The injected-control group received injections of AAV2/2-ChR2GFP virus at $4 \times 10^{12} \mathrm{GP} / \mathrm{ml}$. Animals were used for experiments at least 1 month after viral injection.

Histology/immunohistochemistry and data analysis. Animals were killed by $\mathrm{CO}_{2}$ asphyxiation followed by decapitation and enucleation. Enucleated eyes were fixed in $4 \%$ paraformaldehyde in phosphate buffer (PB) at room temperature (RT) for $20 \mathrm{~min}$. GFP expression was examined in flat-mounted retinas and vertical sections. For vertical sections, fixed retinas were cryoprotected in a sucrose gradient and cryosectioned at $20 \mu \mathrm{m}$ thickness. Slides with cryosections were washed $3 \times 20 \mathrm{~min}$ in PB followed by a 40 min incubation in blocking solution that contained 5\% Chemiblocker (Millipore Bioscience Research Reagents), 0.5\% Triton $\mathrm{X}-100$, and $0.05 \%$ sodium azide. For immunostaining, the following primary antibodies were diluted in blocking solution and applied to sections for overnight RT incubation: mouse anti-ankG (1:20,000; Neuromab), rabbit anti-pan-NF (1:2000; Abcam), mouse anti-Na 1.1 (1: 4000; Neuromab), rabbit anti-SPo (1:60,000; Synaptic Systems), and mouse anti-GlyR $\alpha 1$ (1:4000; Synaptic Systems). The next day, slides were washed $3 \times 20 \mathrm{~min}$ in $\mathrm{PB}$ and secondary antibodies diluted in blocking solution were applied for a $1 \mathrm{~h}$ RT incubation in the dark. Slides were then washed $3 \times 20 \mathrm{~min}$ in $\mathrm{PB}$ and mounted in Vectashield (Vector Laboratories) for fluorescence microscopy. All $z$-stack images were acquired using a Zeiss Axioplan 2 microscope with Apotome (Carl Zeiss) with the AxioVision software. Images were processed using Adobe Photoshop CS5.

The analysis of the relationship between ChR2-GFP-Na $\mathrm{N}_{\mathrm{v}} \mathrm{II}-\mathrm{III}$ expression and $\mathrm{Na}_{\mathrm{v}} 1.1$ immunostaining was performed from collapsed images of retinal vertical sections of retinas injected with low virus concentra- tion. Two mean fluorescence intensities (FIs) were measured in each AII process using ImageJ (obtained from $\mathrm{NIH}$ ) by applying a 5-pixel-wide line tracing the AII process: one for GFP FI and the other for $\mathrm{Na}_{\mathrm{v}} 1.1$ immunostaining FI. Each collapsed image analyzed contained more than three AII processes, with at least one showing GFP labeling without $\mathrm{Na}_{\mathrm{v}} 1.1$ immunostaining, at least one showing $\mathrm{Na}_{\mathrm{v}} 1.1$ immunostaining without GFP labeling, and at least one that is both labeled by GFP and immunostained for $\mathrm{Na}_{\mathrm{v}} 1.1$. The measured FIs for GFP and Na1.1 after background subtraction were normalized to the highest GFP FI and Nal.1 FI, respectively. The normalized $\mathrm{Na}_{\mathrm{v}} 1.1-\mathrm{FI}$ was plotted against the GFP-FI, and the relationship was analyzed using linear regression.

Electrophysiological recordings. Retinal slices were prepared as previously described (Ivanova and Pan, 2009). Whole-cell patch-clamp recordings in control were performed in oxygenized HANKS solution (in mM), as follows: $\mathrm{NaCl} 136.8 ; \mathrm{KCl} 5.4 ; \mathrm{KH}_{2} \mathrm{PO}_{4} 0.4 ; \mathrm{NaH}_{2} \mathrm{PO}_{4} 0.3 ; \mathrm{CaCl}_{2}$ $1.3 ; \mathrm{MgCl}_{2} 0.5 ; \mathrm{MgSO}_{4}$ 0.5; HEPES 5.0; D-glucose 22.0; phenol red 0.03; $\mathrm{pH}$ 7.2. The recordings of current injection-evoked spike activity were performed in HANKS with CNQX $(15 \mu \mathrm{M})$, strychnine $(1 \mu \mathrm{M})$, and picrotoxinin $(50 \mu \mathrm{M})$. The recordings of voltage-gated $\mathrm{Na}^{+}$current were performed in HANKS with $\mathrm{CdCl}_{2}(100 \mu \mathrm{M})$, tetraethylammonium chloride (TEA-Cl; $10 \mathrm{~mm}), \mathrm{CNQX}(15 \mu \mathrm{M})$, strychnine (1 $\mu \mathrm{M})$, and picrotoxinin $(50 \mu \mathrm{M})$. The intracellular solution was as follows (in $\mathrm{mm}$ ): Cs-acetate 130.0; TEA-Cl 10; EGTA 0.1; $\mathrm{MgCl}_{2} 4.0$; HEPES 10; NaATP 2.0; NaGTP 0.5; Alexa Fluor 568 hydrozide sodium salt (Invitrogen) 0.1; $\mathrm{pH}$ 7.4. Tetrodotoxin $(1 \mu \mathrm{M})$ was applied to block $\mathrm{Na}^{+}$current. All chemicals were purchased from Sigma-Aldrich. Liquid junction potential $(3 \mathrm{mV})$ was corrected. The resistance of the electrode was $\sim 8 \mathrm{M} \Omega$. Pipette and cell capacitances were canceled. Data were analyzed off-line using the ORIGIN (Microcal Software) program.

\section{Results}

Viral-mediated $\mathrm{Na}_{\mathrm{v}}$ II-III-targeted expression in the retina

In vivo expression of ChR2-GFP-Na $\mathrm{II}-\mathrm{III}$ in the mouse retina was achieved through AAV2/2-mediated gene delivery by intravitreal injection (Bi et al., 2006). As expected, ChR2-GFP-Na $\mathrm{II}-$ III expression in the retinal ganglion cell (RGC) was concentrated in the AIS (Fig. 1b, arrowheads). In addition, GFP fluorescence 

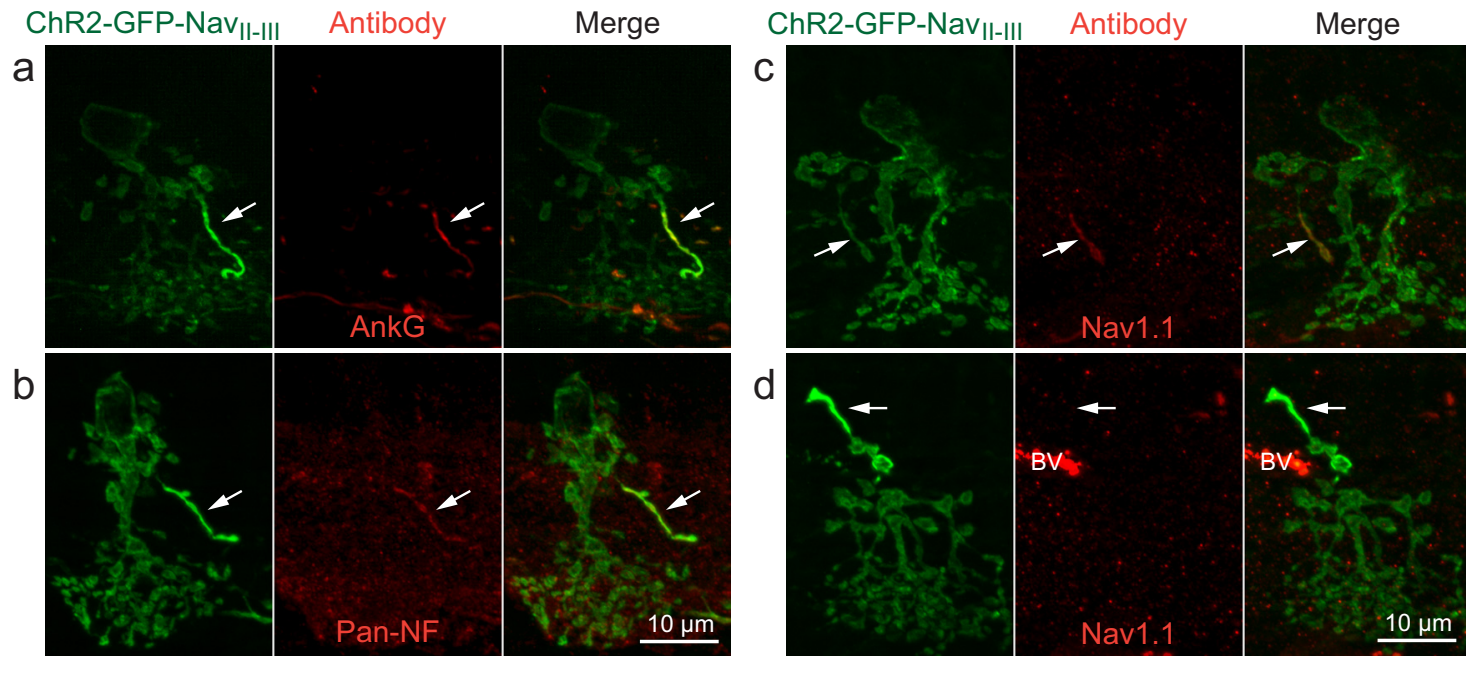

e
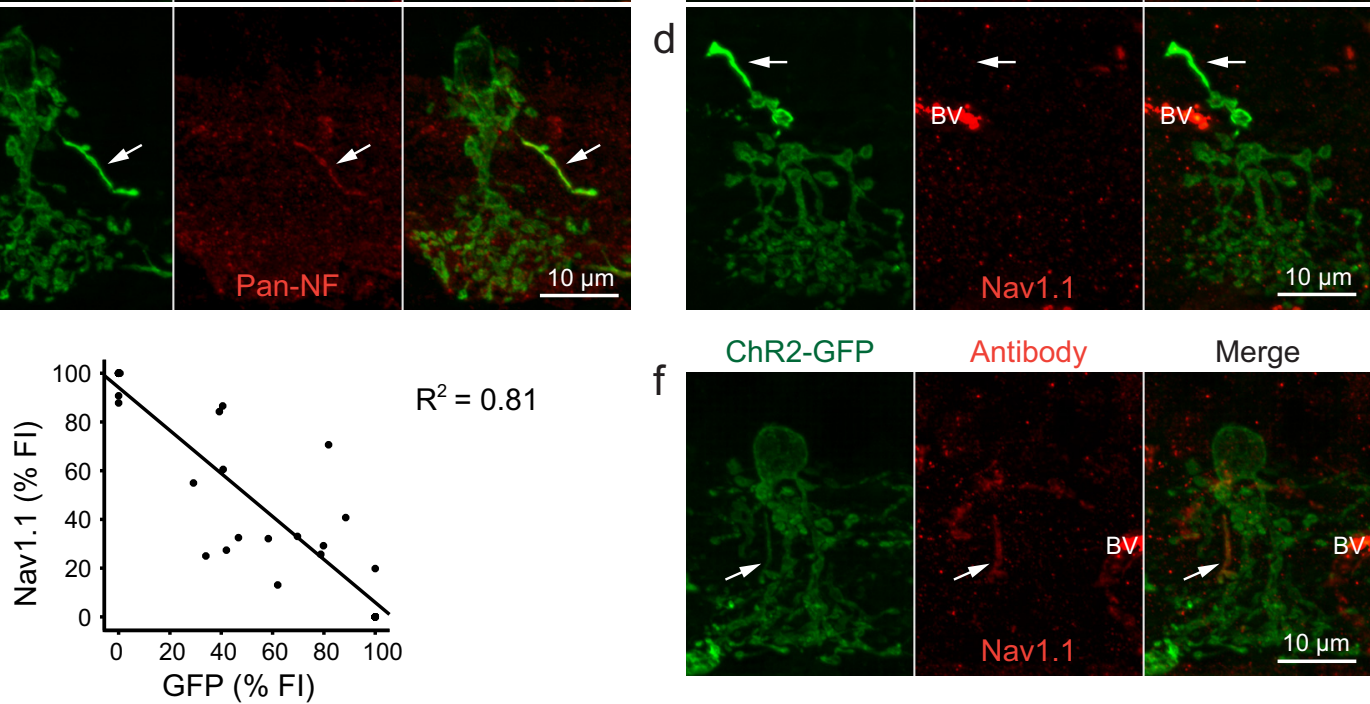

$R^{2}=0.81$

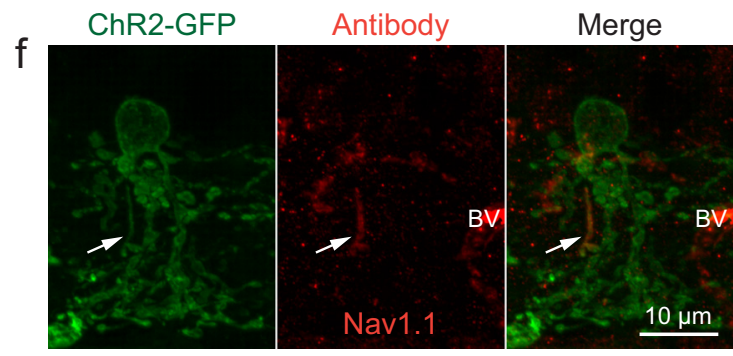

Figure 2. IHC characterization of AIS markers in Na $\mathrm{N} I$-III-targeted All processes. $\boldsymbol{a}, \boldsymbol{b}$, In All cells expressing ChR2-GFP-Na $\mathrm{II}-\mathrm{III}$, All processes colocalized with the AIS markers ankG ( $\boldsymbol{a}$ ) and pan-NF (b). c, In weakly targeted All processes, $\mathrm{Na}_{v} 1.1$ colocalization was observed. $\boldsymbol{d}$, In strongly targeted All processes, Na 1.1 colocalization was not seen. BV, Blood vessel. $\boldsymbol{e}$, Scatter plot with linear regression line summarizing the inverse relationship between the normalized Fls of ChR2-GFP-Na $\mathrm{II}-\mathrm{Ill}$ expression and Na 1.1 immunostaining in ChR2-GFP-Na $\mathrm{II}-\mathrm{III}$ targeted All processes. $\mathrm{f}$, Na $\mathrm{V}$ 1.1 immunostaining also colocalized at an elongated process in nontargeted ChR2-GFP-expressing All cells. All images are collapsed $z$-stack image: $63 \times$ objective; $0.6 \mu \mathrm{m} z$-sections.

was brightly concentrated in smaller processes throughout the IPL (Fig. $1 b$, arrows). We suspected these processes belonged to AII amacrine cells due to the high tropism of AAV2/2 for AII cells (Ivanova and Pan, 2009). Indeed, in vertical section each process (hereafter referred to as the AII process) was found to originate from one AII cell at the lobular appendages. AII processes were varied in orientation and conformation, and terminated in both ON- and OFF-sublaminae of the IPL and occasionally in the inner nuclear layer (INL) (Fig. 1c).

Immunohistochemical staining of AIS-associated proteins in AII processes

Because $\mathrm{Na}_{\mathrm{v}} \mathrm{II}-\mathrm{III}$ is an AIS-targeting motif, we first examined the AII processes with immunohistochemical (IHC) staining for proteins typically enriched at the AIS. $\mathrm{Na}_{\mathrm{v}} \mathrm{II}-\mathrm{III}$ contains an ankyrin binding domain, which binds the cytoskeletal scaffold protein ankyrin-G (ankG) at the AIS (Garrido et al., 2003; Lemaillet et al., 2003). In vertical sections, ankG immunostaining colocalized with AII processes (Fig. 2a). Similarly, pan-neurofascin (pan-NF) immunostaining against an axonal cell adhesion molecule that functions in the organization of the AIS (Sherman et al., 2005; Hedstrom et al., 2007), also colocalized with AII processes (Fig. $2 b$ ).

Since voltage-gated sodium channels cluster at the AIS and in situ hybridization studies have shown AII amacrine cells to express the $\mathrm{Na}_{\mathrm{v}} 1.1$ subunit (Kaneko and Watanabe, 2007), we anticipated every AII process to immunostain positively for $\mathrm{Na}_{\mathrm{v}} 1.1$. However, $\mathrm{Na}_{\mathrm{v}} 1.1$ immunostaining produced a spectrum of results in retinas infected with a low virus concentration (see Materials and Methods). Certain AII processes stained positively for $\mathrm{Na}_{\mathrm{v}} 1.1$ (Fig. $2 c$ ), while others appeared virtually unstained (Fig. $2 d$ ). The $\mathrm{Na}_{\mathrm{v}} 1.1$ staining appeared to be inversely related to the FI of GFP. To quantitatively examine this effect, we measured the FIs of $\mathrm{Na}_{\mathrm{v}} 1.1$ staining and GFP from each individual AII process $(n=31)$. The plot of the normalized $\mathrm{Na}_{\mathrm{v}}$ 1.1-FI against the normalized GFP-FI indeed display an inverse relationship $\left(\beta=-0.90, F_{(1,29)}=121.3, R^{2}=0.81, p<0.001\right)$ (Fig. $2 e)$. The results suggest that the targeted expression of ChR2-GFP$\mathrm{Na}_{\mathrm{v}} \mathrm{II}-\mathrm{III}$ is in competition with endogenous $\mathrm{Na}_{\mathrm{v}} 1.1$ for ankG binding at the AII processes.

Since it might be possible that the expression of ChR2-GFP$\mathrm{Na}_{\mathrm{v}} \mathrm{II}-\mathrm{III}$ also competes with $\mathrm{Na}_{\mathrm{v}} 1.1$ in other processes of AII cells, to further assess the distribution of $\mathrm{Na}_{\mathrm{v}} 1.1$ we examined the $\mathrm{Na}_{\mathrm{v}} 1.1$ staining in GFP-labeled AII cells from eyes injected with virus carrying ChR2-GFP (without the $\mathrm{Na}_{\mathrm{v}} \mathrm{II}$-III motif). $\mathrm{Na}_{\mathrm{v}} 1.1$ immunostaining was only observed in a single elongated process (presumably the AII process) in AII cells, while staining in other processes of AII cells was indistinguishable from the background (Fig. $2 f$ ), similar to the background staining in AII cells expressing ChR2-GFP-Na $\mathrm{II}-\mathrm{III}$ (Fig. 2c,d). These results suggest that $\mathrm{Na}_{\mathrm{v}} 1.1$ channels in the AII cells are predominantly, if not exclusively, localized at the AII process. The competition between ChR2-GFP-Na $\mathrm{II}-\mathrm{III}$ and $\mathrm{Na}_{\mathrm{v}} 1.1$ is therefore likely to be limited to the AII process.

\section{IHC of lobular appendage-associated elements in} AII processes

AII processes have AIS features, yet they still resemble lobular appendages, particularly at the distal ends where lobules are often formed. To explore this relationship, we immunostained for the major synaptic vesicle protein found in lobular appendages, syn- 

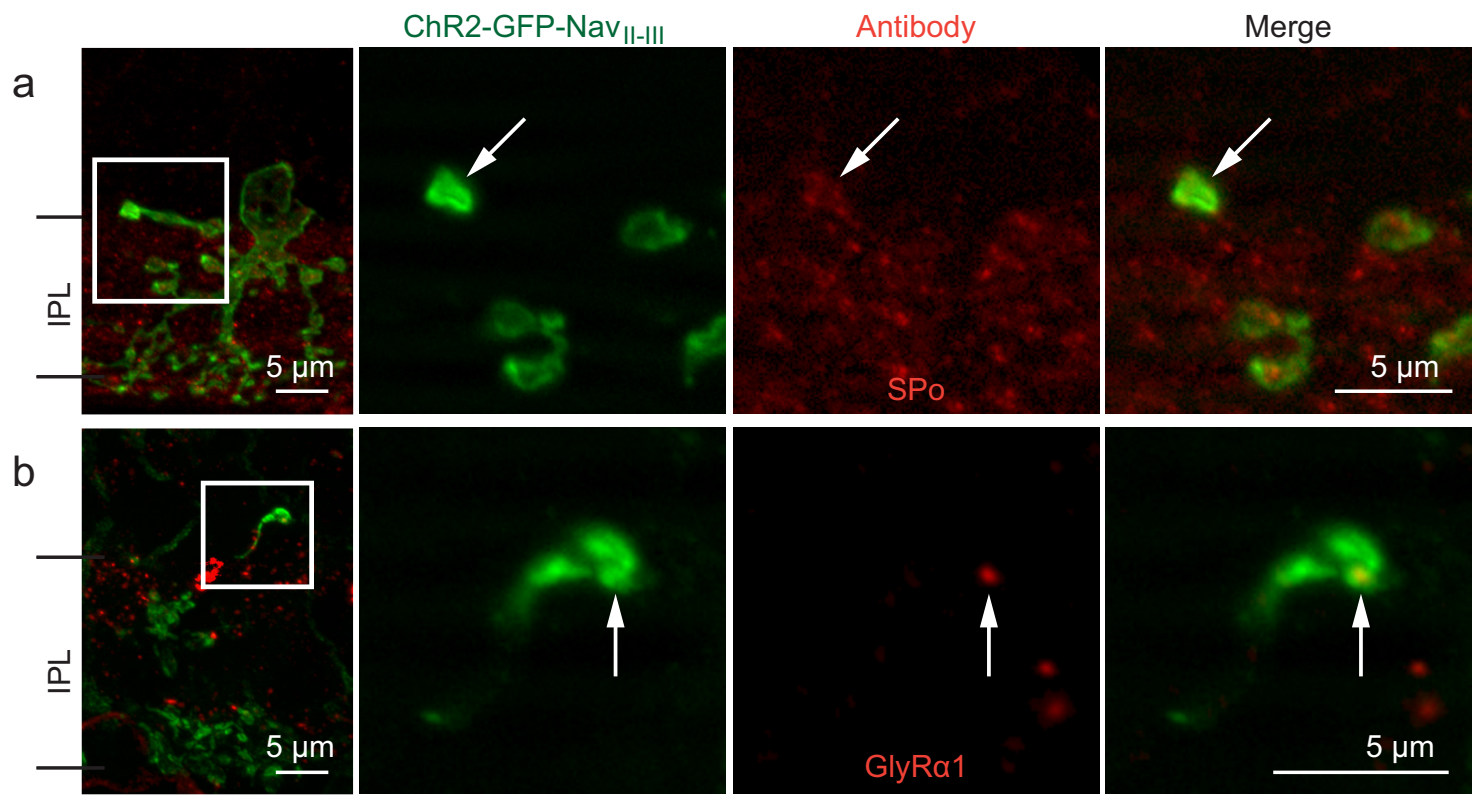

Figure 3. IHC characterization of lobular appendage features in All processes. $\boldsymbol{a}, \boldsymbol{b}$, The first panels are $z$-stack projections ( $20 \times$ objective; $1 \mu \mathrm{m} z$-sections), and three subsequent panels are single-plane magnifications ( $63 \times$ objective, $0.6 \mu \mathrm{m} z$-sections) of the corresponding boxed areas showing an All process terminal colocalizing with SPo immunostaining (a) and an All process colocalizing with a GlyR $\alpha 1$ punctum (b).

a ChR2-GFP

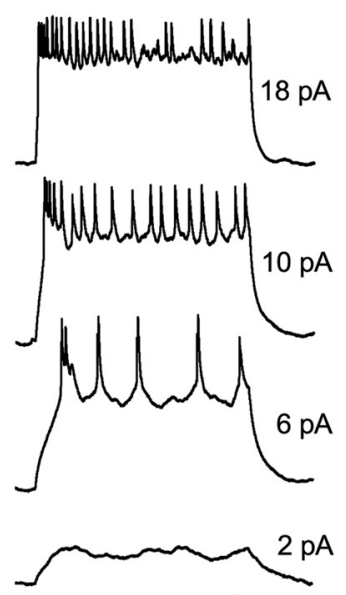

$I_{H}=-8 p A$ b ChR2-GFP-Na
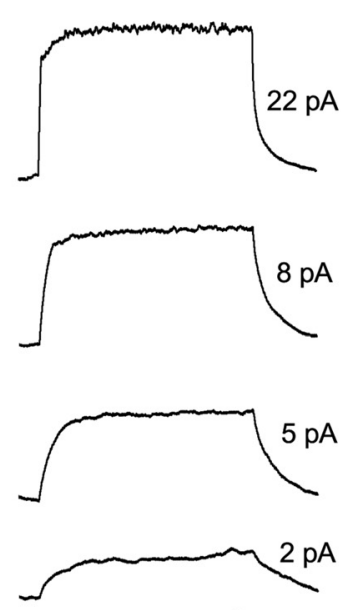

$$
20 \mathrm{mV}
$$

$20 \mathrm{mV}$

\section{ChR2-GFP}

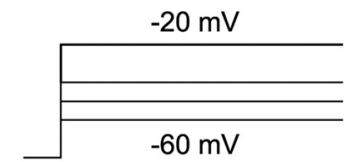

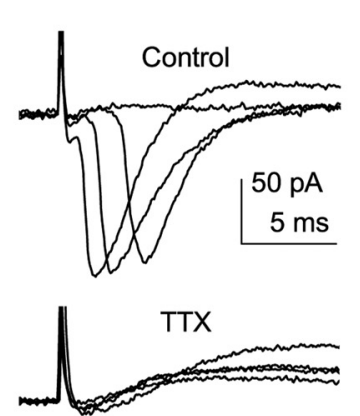

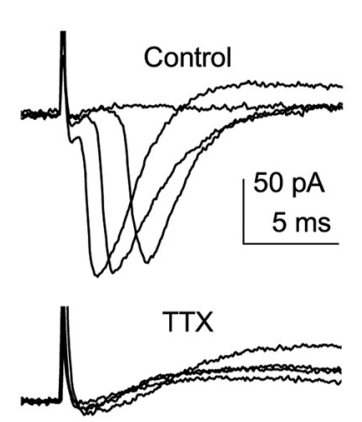

d ChR2-GFP-Na ${ }_{\text {II-III }}$
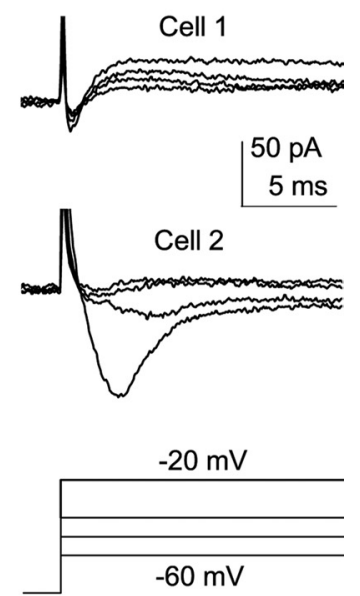

Figure 4. Patch-clamp recordings of $\mathrm{Na}^{+}$channel-mediated action potentials and $\mathrm{Na}^{+}$current in All cells. $\boldsymbol{a}, \boldsymbol{b}$, Depolarizing current injections from $\sim-80 \mathrm{mV}$ elicited spikes in an All cell in the control group $(\boldsymbol{a})$, but not in the $\mathrm{Na}_{\mathrm{v}} \mathrm{Il}-\mathrm{III}$ targeted group $(\boldsymbol{b})$. Injection currents relative to the holding current are shown. $\boldsymbol{c}, \boldsymbol{d}, \mathrm{Na}^{+}$currents activated by membrane depolarization of All cells from the holding potential of $-80 \mathrm{mV}$. c, Top, A representative recording from a cell in the control group. Bottom, The current in the same cell was blocked by $1 \mu \mathrm{m}$ TTX. $\boldsymbol{d}$, Recordings from the Na III-III targeted group of a cell with no $\mathrm{Na}^{+}$current (cell 1, top) and a cell with the largest $\mathrm{Na}^{+}$current (cell 2, bottom).

aptoporin (SPo) (Brandstätter et al., 1996). In vertical sections, 97\% $(n=58)$ of AII processes examined colocalized with SPo immunostaining (Fig. 3a). To investigate whether AII processes potentially had a postsynaptic partner, we immunostained vertical sections with antibodies against the glycine receptor $\alpha 1$ subunit (GlyR $\alpha 1$ ) postsynaptic to lobular appendages (Sassoè-Pognetto et al., 1994; Grünert and Wässle, 1996). When $\mathrm{Na}_{\mathrm{v}}$ II-III expressing AII processes were examined, $84 \%(n=45)$ appeared to colocalize with GlyR $\alpha 1$ puncta (Fig. $3 b)$ (GlyR $\alpha 1$ ). These results suggest that AII processes likely contain the sites of presynaptic glycine release.
Patch-clamp characterization of $\mathrm{Na}_{\mathrm{v}}$ II-III-targeting on AII cell spiking

Because the expression of ChR2-GFP-Na $\mathrm{VII}$-III disrupts endogenous $\mathrm{Na}_{\mathrm{v}} 1.1$ clustering in AII processes, we examined this effect on the spiking ability of AII amacrine cells by performing wholecell patch-clamp recordings in retinal slices. We first examined action potentials evoked by current injection in current-clamp with the suppression of all synaptic inputs. As a control, we recorded GFP-labeled AII cells from eyes injected with virus carrying ChR2-GFP without the $\mathrm{Na}_{\mathrm{v}} \mathrm{II}-\mathrm{III}$ motif. Consistent with 
previous reports (Boos et al., 1993; Tamalu and Watanabe, 2007), spike-like potentials were evoked in the majority of recorded AII cells (11 of 13) (Fig. 4a). In contrast to the control, no spike-like potential was observed with current injection in any of the recorded AII cells in the $\mathrm{Na}_{\mathrm{v}} \mathrm{II}-\mathrm{III}$ targeted group $(n=7)$ (Fig. $\left.4 b\right)$. For every cell recorded in both groups, the functional expression of ChR2 was confirmed by the ChR2-mediated light responses (data not shown). Thus, AII amacrine cells with $\mathrm{Na}_{\mathrm{v}} \mathrm{II}-\mathrm{III}$ motiftargeted expression of ChR2-GFP lost their spike firing ability.

We next compared the voltage-gated $\mathrm{Na}^{+}$current between control and $\mathrm{Na}_{\mathrm{v}} \mathrm{II}-\mathrm{III}$ targeted groups. The recordings were made under the condition that other voltage-gated currents and neurotransmitter-activated receptors were blocked to isolate $\mathrm{Na}^{+}$currents. $\mathrm{Na}^{+}$currents were observed in the majority of recorded AII cells in the control group (5 of 7) (Fig. 4c) but were barely detected in the majority of the $\mathrm{Na}_{\mathrm{v}} \mathrm{II}$-III-targeted group (Fig. $4 d$, top). Only in a few cells ( 3 of 13 ) were small or moderate $\mathrm{Na}^{+}$currents observed (Fig. $4 d$, bottom). The current observed in these few cells is likely due to the variable disruption of $\mathrm{Na}_{\mathrm{v}} 1.1$ at the AII process. The average ( \pm SEM) peak current for the control group $(84.3 \pm 24.7 ; n=7)$ was significantly different from that of the $\mathrm{Na}_{\mathrm{v}} \mathrm{II}-\mathrm{III}$ targeted group (6.4 $\pm 4.3 \mathrm{SEM} ; n=13$; $p<0.001$, two-tailed $t$ test). Together, these results indicate that targeted ChR2-GFP-Na $\mathrm{v}$ II-III expression largely abolished $\mathrm{Na}^{+}$ currents along with the spiking ability of AII amacrine cells.

\section{Discussion}

In this study, we revealed the clustering of $\mathrm{Na}^{+}$channels at an AIS-like process in the AII amacrine cell. We also demonstrated that the clustering of $\mathrm{Na}^{+}$channels in the process is essential for spike generation in this axonless neuron. These AIS-like processes are likely the morphologically distinct processes immunolabeled by $\mathrm{Na}_{\mathrm{v}} 1.1$, ankyrin- $\mathrm{G}$ and neurofascin reported in the rat retina (Van Wart et al., 2005), but the previous study was unable to link these processes to their cells of origin. Our results thus show an advantage of motiftargeted fluorescent protein expression in identifying this elusive compartment in the AII amacrine cell.

In several aspects, the AII processes resemble the lobular appendages because they originate at the primary dendrite and terminate with lobular appearance where lobular appendageassociated elements are expressed. However, unlike the classic lobular appendages, the processes were found to terminate throughout the IPL and even in the INL. In addition, the AII processes are generally longer and more slender than the typical lobular appendages. Therefore, the AII process appears to be morphologically distinct from conventional lobular appendages.

What might be the functional role of $\mathrm{Na}^{+}$channel clustering at this unconventional AIS-like process in the AII amacrine cell? First, as in the case of AIS in the axon-bearing neurons, the AISlike process could facilitate spiking by lowering the threshold of spike generation in AII cells (Kole et al., 2008). Second, since the terminal of AII processes appear to contain functional synapses, the clustering of $\mathrm{Na}^{+}$channels would be expected to elicit strong neurotransmitter release from this particular site and, thus, provide fast inhibitory signaling, possibly to both ON and OFF downstream pathways. Furthermore, the AII process is likely to be electrotonically closer to the lobular appendages than the arboreal dendrites. Therefore, the AIS-like process may serve to differentially amplify and accelerate rod signals (Boos et al., 1993; Smith and Vardi, 1995) to downstream ON and OFF pathways. However, a recent study reported that although AII cell action potentials accelerated the light response of RGCs, blocking voltage-gated $\mathrm{Na}^{+}$channels did not differentially affect $\mathrm{ON}$ and OFF responses or attenuate the response amplitudes of RGCs in scotopic vision (Tian et al., 2010). The latter is surprising because action potentials in AII cells have been shown to be able to transmit through electrical synapses between AII cells and to downstream cone bipolar cells (Veruki and Hartveit, 2002a,b). Since the spiking ability of AII cells is dependent on their membrane potentials and possibly modulated by other factors (Boos et al., 1993; Tian et al., 2010), the functional role of voltage-gated $\mathrm{Na}^{+}$ channels and the clustering of the $\mathrm{Na}^{+}$channels of AII cells in rod signal processing needs to be further investigated. Finally, with extensive synaptic connectivity with at least 12 different classes of retinal neurons (Anderson et al., 2011) and the recent findings of new roles of AII cells in photopic vision (Manookin et al., 2008; Münch et al., 2009), it also remains to be studied whether AII cell action potentials generated at this AIS-like process could play a role in other information pathways.

Amacrine cells are the most morphologically and functionally diverse cell class in the retina (Masland, 1988). Action potentials mediated by voltage-gated $\mathrm{Na}^{+}$channels in amacrine cells have also been reported to contribute to the receptive field size and directional selectivity of RGCs (Bloomfield, 1996; Oesch and Taylor, 2010). Dendritic spiking was proposed to play a role in the information processing of amacrine cells by computer modeling (Royer and Miller, 2007). The discovery of the AIS-like process in AII cells may offer new insights into the localization and function of voltage-gated $\mathrm{Na}^{+}$channels in other spiking amacrine cells.

It remains to be seen whether the presence of AIS-like processes in axonless neurons could be a general feature in the CNS. Supporting such possibility, patch-like segments with AIScharacteristics have been reported in the dendritic processes of olfactory bulb granule cells (Kosaka et al., 2008), a population of axonless spiking interneurons that play a role in odor discrimination (Abraham et al., 2010). The same methods could be used to visualize possible AIS-like processes and assess their functional roles in axonless neurons in other regions of the nervous system. The approach of motif targeting could be a valuable tool for studying the structure and function of the CNS.

\section{References}

Abraham NM, Egger V, Shimshek DR, Renden R, Fukunaga I, Sprengel R, Seeburg PH, Klugmann M, Margrie TW, Schaefer AT, Kuner T (2010) Synaptic inhibition in the olfactory bulb accelerates odor discrimination in mice. Neuron 65:399-411.

Anderson JR, Jones BW, Watt CB, Shaw MV, Yang J-H, Demill D, Lauritzen JS, Lin YH, Rapp KD, Mastronarde D, Koshevoy P, Grimm B, Tasdizen T, Whitaker R, Marc RE (2011) Exploring the retinal connectome. Mol Vis 17:355-379.

Bi A, Cui J, Ma YP, Olshevskaya E, Pu M, Dizhoor AM, Pan ZH (2006) Ectopic expression of a microbial-type rhodopsin restores visual responses in mice with photoreceptor degeneration. Neuron 50:23-33.

Bloomfield SA (1996) Effect of spike blockade on the receptive-field size of amacrine and ganglion cells in the rabbit retina. J Neurophysiol 75:1878-1893.

Bloomfield SA, Dacheux RF (2001) Rod vision: pathways and processing in the mammalian retina. Prog Retin Eye Res 20:351-384.

Boos R, Schneider H, Wässle H (1993) Voltage-and transmitter-gated currents of all-amacrine cells in a slice preparation of the rat retina. J Neurosci 13:2874-2888

Brandstätter JH, Löhrke S, Morgans CW, Wässle H (1996) Distributions of two homologous synaptic vesicle proteins, synaptoporin and synaptophysin, in the mammalian retina. J Comp Neurol 370:1-10.

Coombs JS, Curtis DR, Eccles JC (1957) The generation of impulses in motoneurones. J Physiol 139:232-249.

Famiglietti EV Jr, Kolb H (1975) A bistratified amacrine cell and synaptic cirucitry in the inner plexiform layer of the retina. Brain Res 84:293-300. 
Garrido JJ, Giraud P, Carlier E, Fernandes F, Moussif A, Fache MP, Debanne D, Dargent B (2003) A targeting motif involved in sodium channel clustering at the axonal initial segment. Science 300:2091-2094.

Grubb MS, Burrone J (2010a) Activity-dependent relocation of the axon initial segment fine-tunes neuronal excitability. Nature 465:1070-1074.

Grubb MS, Burrone J (2010b) Channelrhodopsin-2 localised to the axon initial segment. PLoS One 5:e13761.

Grünert U, Wässle H (1996) Glycine receptors in the rod pathway of the macaque monkey retina. Vis Neurosci 13:101-115.

Hedstrom KL, Xu X, Ogawa Y, Frischknecht R, Seidenbecher CI, Shrager P, Rasband MN (2007) Neurofascin assembles a specialized extracellular matrix at the axon initial segment. J Cell Biol 178:875-886.

Ivanova E, Pan ZH (2009) Evaluation of the adeno-associated virus mediated long-term expression of channelrhodopsin-2 in the mouse retina. Mol Vis 15:1680-1689.

Kaneko Y, Watanabe S (2007) Expression of Navl.1 in rat retinal AII amacrine cells. Neurosci lett 424:83-88.

Kole MH, Ilschner SU, Kampa BM, Williams SR, Ruben PC, Stuart GJ (2008) Action potential generation requires a high sodium channel density in the axon initial segment. Nat Neurosci 11:178-186.

Kosaka T, Komada M, Kosaka K (2008) Sodium channel cluster, $\beta$ IVspectrin and ankyrinG positive "hot spots" on dendritic segments of parvalbumin-containing neurons and some other neurons in the mouse and rat main olfactory bulbs. Neurosci Res 62:176-186.

Kuba H, Oichi Y, Ohmori H (2010) Presynaptic activity regulates $\mathrm{Na}^{+}$ channel distribution at the axon initial segment. Nature 465:1075-1078.

Lai HC, Jan LY (2006) The distribution and targeting of neuronal voltagegated ion channels. Nat Rev Neurosci 7:548-562.

Lemaillet G, Walker B, Lambert S (2003) Identification of a conserved ankyrin-binding motif in the family of sodium channel alpha subunits. J Biol Chem 278:27333-27339.

Losonczy A, Makara JK, Magee JC (2008) Compartmentalized dendritic plasticity and input feature storage in neurons. Nature 452:436-441.

Manookin MB, Beaudoin DL, Ernst ZR, Flagel LJ, Demb JB (2008) Disinhibition combines with excitation to extend the operating range of the OFF visual pathway in daylight. J Neurosci 28:4136-4150.

Masland RH (1988) Amacrine cells. Trends Neurosci 11:405-410.

Münch TA, da Silveira RA, Siegert S, Viney TJ, Awatramani GB, Roska B
(2009) Approach sensitivity in the retina processed by a multifunctional neural circuit. Nat Neurosci 12:1308-1316.

Oesch NW, Taylor WR (2010) Tetrodotoxin-resistant sodium channels contribute to directional responses in starburst amacrine cells. PLoS One 5:e12447.

Palmer LM, Stuart GJ (2006) Site of action potential initiation in layer 5 pyramidal neurons. J Neurosci 26:1854-1863.

Royer AS, Miller RF (2007) Dendritic impulse collisions and shifting sites of action potential initiation contract and extend the receptive field of an amacrine cell. Vis Neurosci 24:619-634.

Sassoè-Pognetto M, Wässle H, Grünert U (1994) Glycinergic synapses in the rod pathway of the rat retina: cone bipolar cells express the $\alpha 1$ subunit of the glycine receptor. J Neurosci 14:5131-5146.

Sherman DL, Tait S, Melrose S, Johnson R, Zonta B, Court FA, Macklin WB, Meek S, Smith AJ, Cottrell DF, Brophy PJ (2005) Neurofascins are required to establish axonal domains for saltatory conduction. Neuron 48:737-742.

Smith RG, Vardi N (1995) Simulation of the AII amacrine cell of mammalian retina: functional consequences of electrical coupling and regenerative membrane properties. Vis Neurosci 12:851-860.

Tamalu F, Watanabe S (2007) Glutamatergic input is coded by spike frequency at the soma and proximal dendrite of AII amacrine cells in the mouse retina. Eur J Neurosci 25:3243-3252.

Tian M, Jarsky T, Murphy GJ, Rieke F, Singer JH (2010) Voltage-gated Na channels in AII amacrine cells accelerate scotopic light responses mediated by the rod bipolar cell pathway. J Neurosci 30:4650-4659.

Van Wart A, Boiko T, Trimmer JS, Matthews G (2005) Novel clustering of sodium channel $\mathrm{Na}(\mathrm{v}) 1.1$ with ankyrin- $\mathrm{G}$ and neurofascin at discrete sites in the inner plexiform layer of the retina. Mol Cell Neurosci 28:661-673.

Veruki ML, Hartveit E (2002a) AII (Rod) amacrine cells form a network of electrically coupled interneurons in the mammalian retina. Neuron 33:935-946.

Veruki ML, Hartveit E (2002b) Electrical synapses mediate signal transmission in the rod pathway of the mammalian retina. J Neurosci 22: $10558-10566$

Xin D, Bloomfield SA (1999) Comparison of the responses of AII amacrine cells in the dark- and light-adapted rabbit retina. Vis Neurosci 16:653665. 